\title{
BLOOD AND EXTRACELLULAR FLUID STUDIES IN CHRONIC MALNUTRITION IN INFANCY ${ }^{1,2}$
}

\author{
By FRANK GOLLAN 3, 4
}

(Received for publication September 29, 1947)

One problem facing the Italian Medical Nutrition Mission in 1945-46 was the great number of infants and children suffering from severe and chronic malnutrition. Through lack of sanitation, milk control and proper food, cases of severe inanition were encountered quite frequently in southern Italy.

The obvious dehydration of these emaciated infants on one hand and the poor results obtained with intravenous fluid therapy on the other hand suggested that there existed a severe disturbance of the distribution of body water rather than a simple deficiency in body fluids. Studies under the actual conditions of a war-torn and povertystricken country seemed therefore to be desirable.

\section{METHODS AND MATERIAL}

\section{Clinical material}

Twenty-three cases of severe marasmus in infancy and six cases of chronic malnutrition in older children were examined and 55 observations were made. Prior to being admitted to the Annunziata Hospital in Naples these infants had suffered generally from several attacks of gastro-intestinal disturbances, particularly diarrhea and vomiting, which presumably caused their initial loss of

1 The present studies are a part of the work of the Italian Medical Nutrition Mission, 1945-46. This Mission was sponsored by the Unitarian Service Committee, The Congregational Christian Service Committee and the Health Department of the United Nations Relief and Rehabilitation Administration under the scientific codirectorship of Dr. Elmer L. Sevringhaus, Nutley, New Jersey, and Dr. Maurice B. Visscher, Minneapolis, Minnesota.

2 I am greatly indebted to Miss Dorothy Hagedorn and Miss Marjorie Knowlton for their efficient technical assistance under unusual conditions and to Drs. Mario Sagese and Vincenzo Baffi from the Pediatric Clinic in Naples for their understanding cooperation. My sincere thanks go to Prof. Dr. Ruggiero Vaglio, humanitarian and scientist, for having offered to me his clinical facilities and material of the Annunziata Hospital in Naples, and to Prof. Dr. Luigi Auricchio for having made available to me the laboratories of the Pediatric Clinic in Naples.

${ }^{8}$ Surgeon/R/, U. S. Public Health Service.

4 Present address: Department of Physiology, University of Minnesota Medical School, Minneapolis 14. weight. With the coming of the colder season these diarrheal attacks ceased but the children failed to gain weight. Most of the time they suffered from anorexia and occasionally from vomiting. Many were afflicted with thrush, scabies, impetigo or bed sores. None of the children showed signs of nutritional edema. Their dietary regime consisted of milk mixtures or whole milk with the addition of flour. Their fluid intake was comparatively low since anorexia was prevalent and additional fluid in the form of tea was offered only occasionally.

After many weeks of failure to gain weight or continued weight loss, the majority of the children developed all the clinical signs of marasmus and died in a condition of extreme inanition or of intercurrent infections.

In order to determine the degree of malnutrition the actual weight of the child was compared with the height and weight of standard American children (1). Since these standard average values would produce a comparison with a hypothetical standard individual another method was also used which would allow a greater individualization. Therefore the "calculated weight" was established for all infants examined. This calculated weight (2) is based on the formula:

$$
\frac{\text { chest circumference }^{2}}{\mathrm{~K}} \times \text { height } \times \text { spec. gravity. }
$$

The measurements of the chest circumference and the height are the only data required. Calculations are simplified by the use of a nomogram. Chest circumferences were measured at xiphoid level and at quiet expiration. Height was measured in prone or supine position. Body surface was determined from the same data by the use of the $\mathrm{Du}$ Bois formula (3).

\section{Biochemical methods}

For the determination of hemoglobin, hematocrit and plasma protein the specific gravity method was used (4). Albumin and globulin were determined with the method of Greenberg (5). Non-protein nitrogen determinations were carried out with the method of Wong-Buell and Archibald (6).

For the simultaneous determination of plasma volume and extracellular fluid space the method of Gregersen and Stewart (7) was adopted and modified for the Coleman Junior Clinical Spectrophotometer Model 6. For the children up to $6 \mathrm{~kg}$., $1 \mathrm{mg}$. of the dye T-1824 was injected; for children from 6 to $20 \mathrm{~kg}$., $3.3 \mathrm{mg}$.; and for older children above $20 \mathrm{~kg}$., the usual dose for adults of $10 \mathrm{mg}$. was injected. To determine the extracellular fluid space a sterile solution of 10 per cent $\mathrm{Na}$ SCN was added to the dye in proportions not to exceed $20 \mathrm{mg}$. per 
kg. of weight. For children up to $6 \mathrm{~kg}$., $60 \mathrm{mg}$. Na SCN were injected; from 6 to $20 \mathrm{~kg}$., $200 \mathrm{mg}$.; and for children above $20 \mathrm{~kg}$., $400 \mathrm{mg}$. All intravenous injections and withdrawals of blood were made in the longitudinal sinus. No accidents or reactions were encountered.

For the determinations of sodium in the plasma the method of Butler and Tuthill (8) was used. For chloride in the plasma the method of Van Slyke and Sendroy (9) was employed.

\section{Material}

Table I shows all data used for the analysis of the encountered condition.

Of the 23 infants examined 14 were males and nine were females. The age ranged from six weeks to two years and nine months. Only three infants were older than one year.

As noted above, all children suffered from chronic malnutrition. In 18 infants the cause of malnutrition

TABLE I

\begin{tabular}{|c|c|c|c|c|c|c|c|c|c|c|}
\hline No. & & Age & & Diagnosis & Weight & Hemogl. & $\begin{array}{c}\text { Plasma } \\
\text { prot. }\end{array}$ & $\begin{array}{c}\text { Plasma } \\
\text { vol. }\end{array}$ & $\begin{array}{c}\text { T-1824 } \\
\text { dis. rate }\end{array}$ & Extracell. fl. \\
\hline 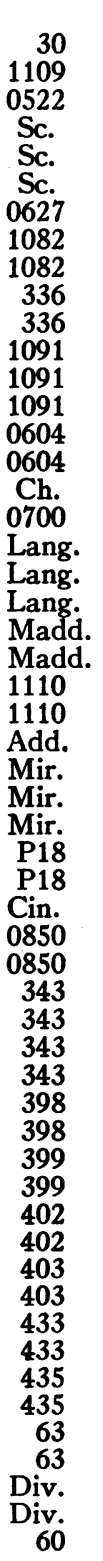 & $\begin{array}{r}9 \\
9 \\
9 \\
9 \\
6 \\
6 \\
10 \\
10 \\
9 \\
9 \\
10 \\
10 \\
2 \\
2\end{array}$ & $\begin{array}{r}\text { mo } \\
2 \\
1 \\
4 \\
14 \\
14 \\
14 \\
3 \\
3 \\
3\end{array}$ & $\begin{array}{r}w k . \\
1 \\
1 \\
3 \\
2 \\
3 \\
2 \\
2 \\
\\
2 \\
3 \\
3 \\
1 \\
1 \\
2 \\
1 \\
2 \\
2 \\
3 \\
1 \\
3 \\
2 \\
2 \\
2 \\
2 \\
3 \\
3 \\
1 \\
4 \\
4 \\
5 \\
8\end{array}$ & $\begin{array}{l}\text { Malnutr. } \\
\text { Malnutr. } \\
\text { Malnutr. } \\
\text { Malnutr. } \\
\text { Malnutr. } \\
\text { Malnutr. } \\
\text { Malnutr. } \\
\text { Malnutr. } \\
\text { Malnutr. } \\
\text { Malnutr. } \\
\text { Malnutr. } \\
\text { Malnutr. } \\
\text { Malnutr. } \\
\text { Malnutr. } \\
\text { Malnutr. } \\
\text { Malnutr. } \\
\text { Brain tumor } \\
\text { Malnutr. } \\
\text { Malnutr. } \\
\text { Malnutr. } \\
\text { Malnutr. } \\
\text { Pylor. sten. } \\
\text { Pylor. sten. } \\
\text { Malnutr. } \\
\text { Malnutr. } \\
\text { Pylor. sten. } \\
\text { Malnutr. } \\
\text { Malnutr. } \\
\text { Malnutr. } \\
\text { Malnutr. } \\
\text { Malnutr. } \\
\text { Pylor. sten. } \\
\text { Malnutr. } \\
\text { Malnutr. } \\
\text { Malnutr. } \\
\text { Malnutr. } \\
\text { Malnutr. } \\
\text { Malnutr. } \\
\text { Malnutr. } \\
\text { Malnutr. } \\
\text { Malnutr. } \\
\text { Malnutr. } \\
\text { Malnutr. } \\
\text { Malnutr. } \\
\text { Malnutr. } \\
\text { Malnutr. } \\
\text { Malnutr. } \\
\text { Malnutr. } \\
\text { Malnutr. } \\
\text { Malnutr. } \\
\text { Malnutr. } \\
\text { Malnutr. } \\
\text { Wilms tumor } \\
\text { Wilms tumor } \\
\text { Malnutr. }\end{array}$ & $\begin{array}{r}k 3 . \\
2.9 \\
2.7 \\
2.8 \\
4.5 \\
4.1 \\
4.2 \\
2.7 \\
2.4 \\
2.4 \\
2.4 \\
5.2 \\
7.2 \\
3.5 \\
3.6 \\
3.4 \\
3.4 \\
2.9 \\
4.2 \\
9.2 \\
2.5 \\
2.5 \\
2.9 \\
3.3 \\
3.6 \\
3.7 \\
3\end{array}$ & $\begin{array}{r}g m . \% \\
8.6 \\
11.8 \\
8.1 \\
11.4 \\
14.0 \\
11.2 \\
10.5 \\
9.3 \\
8.9 \\
6.9 \\
7.3 \\
11.7 \\
9.7 \\
10.9 \\
10.9 \\
12.0 \\
14.0 \\
10.7 \\
9.7 \\
10.2 \\
10.5 \\
11.2 \\
11.8 \\
9.4 \\
8.5 \\
13.1 \\
11.6 \\
10.3 \\
8.8 \\
15.6 \\
11.6 \\
11.2 \\
11.6 \\
10.8 \\
7.8 \\
9.4 \\
9.5 \\
9.9 \\
13.8 \\
13.4 \\
11.8 \\
12.2 \\
13.2 \\
14.2 \\
13.3 \\
12.9 \\
13.8 \\
13.4 \\
12.6 \\
13.9 \\
12.2 \\
11.8 \\
7.5 \\
11.7\end{array}$ & $\begin{array}{c}\boldsymbol{g} .7 \\
7.7 \\
5.1 \\
4.4 \\
6.1 \\
5.8 \\
5.8 \\
5.1 \\
6.8 \\
6.1 \\
7.2 \\
6.8 \\
6.8 \\
5.5 \\
6.2 \\
7.2 \\
5.8 \\
5.8 \\
5.8 \\
5.8 \\
5.5 \\
5.8 \\
6.1 \\
6.2 \\
5.8 \\
6.5 \\
5.1 \\
4.8 \\
5.8 \\
5.8 \\
5.5 \\
4.8 \\
5.1 \\
4.8 \\
5.1 \\
4.4 \\
4.8 \\
5.6 \\
6.8 \\
7.2 \\
7.2 \\
7.2 \\
6.8 \\
6.8 \\
7.2 \\
6.8 \\
7.2 \\
7.2 \\
7.2 \\
6.8 \\
7.2 \\
6.8 \\
6.8 \\
7.7 \\
7.2 \\
6.8\end{array}$ & 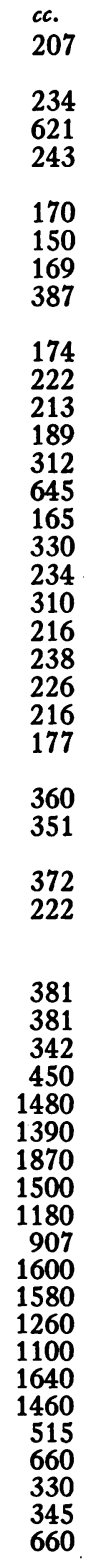 & $\begin{array}{c}\% \text { per } \mathrm{hr} . \\
31.5 \\
\\
28.0 \\
20.5 \\
20.2 \\
6.0 \\
16.0 \\
13.0 \\
\\
7.5 \\
28.0 \\
18.0 \\
11.5 \\
9.0 \\
13.6 \\
19.5 \\
14.0 \\
12.0 \\
22.5 \\
19.0 \\
22.0 \\
4.2 \\
14.0 \\
\end{array}$ & $\begin{array}{r}c c . \\
909 \\
1333 \\
1090 \\
1935 \\
1579 \\
1250 \\
1032 \\
699 \\
863 \\
1818 \\
2927 \\
883 \\
1304 \\
1223 \\
909 \\
1463 \\
4190 \\
882 \\
993 \\
1176 \\
1220 \\
1304 \\
1250 \\
1250 \\
1177 \\
1071 \\
1580 \\
1764 \\
2222 \\
1200 \\
1500 \\
1540 \\
1250 \\
1154 \\
1818 \\
2166 \\
2857 \\
8166 \\
7407 \\
7339 \\
7547 \\
5519 \\
5555 \\
7700 \\
7273 \\
5940 \\
6154 \\
7690 \\
7500 \\
3333 \\
1765 \\
3030\end{array}$ \\
\hline
\end{tabular}


TABLE II

Physical measurements of 13 marasmic infants

\begin{tabular}{|c|c|c|c|c|c|c|c|c|c|}
\hline No. & Age & Weight & Height & $\begin{array}{l}\text { Chest } \\
\text { circum. }\end{array}$ & $\begin{array}{c}\text { Calc. } \\
\text { weight }\end{array}$ & $\begin{array}{l}\text { American } \\
\text { Standard } \\
\text { weight }\end{array}$ & Surface & $\begin{array}{c}\text { Reta } \\
\text { in de } \\
\mathrm{m}\end{array}$ & $\begin{array}{l}\text { ation } \\
\text { lop- } \\
\text { t }\end{array}$ \\
\hline $\begin{array}{c}0522 \\
\text { Sc. } \\
0627 \\
1082 \\
336 \\
1091 \\
0604 \\
0700 \\
\text { Lang. } \\
1110 \\
\text { Mir. } \\
0850 \\
343 \\
\text { Average } \\
\text { Normal }\end{array}$ & $\begin{array}{r}m o . \\
4.3 \\
14.0 \\
3.0 \\
3.2 \\
20.0 \\
3.2 \\
3.3 \\
3.1 \\
3.0 \\
2.1 \\
7.2 \\
2.3 \\
13.0 \\
6.0 \\
6.2\end{array}$ & $\begin{array}{r}\text { kg. } \\
2.8 \\
4.4 \\
2.7 \\
2.4 \\
5.2 \\
3.5 \\
2.9 \\
2.5 \\
2.9 \\
2.8 \\
4.0 \\
2.9 \\
4.8 \\
3.4 \\
7.3\end{array}$ & $\begin{array}{l}c m . \\
53.5 \\
66.0 \\
50.5 \\
48.5 \\
64.0 \\
54.5 \\
51.0 \\
46.5 \\
51.5 \\
49.0 \\
57.5 \\
50.5 \\
60.5 \\
54.1 \\
66.0\end{array}$ & $\begin{array}{l}c m . \\
32.9 \\
39.4 \\
33.6 \\
29.5 \\
39.8 \\
33.0 \\
33.8 \\
28.9 \\
34.8 \\
33.3 \\
37.8 \\
32.4 \\
39.2 \\
34.5 \\
43.5\end{array}$ & $\begin{array}{r}\text { kg. } \\
3.6 \\
6.4 \\
3.6 \\
2.8 \\
6.4 \\
3.7 \\
3.7 \\
2.5 \\
3.9 \\
3.5 \\
5.2 \\
3.8 \\
5.8 \\
4.2 \\
7.6\end{array}$ & \begin{tabular}{r}
\multicolumn{1}{c}{$k g}$. \\
6.8 \\
9.8 \\
5.7 \\
6.0 \\
12.5 \\
6.4 \\
6.4 \\
5.8 \\
6.1 \\
5.5 \\
8.6 \\
5.5 \\
10.8 \\
7.3 \\
7.3
\end{tabular} & $\begin{array}{c}\text { sq. } m . \\
0.200 \\
0.280 \\
0.190 \\
0.174 \\
0.300 \\
0.223 \\
0.195 \\
0.172 \\
0.196 \\
0.186 \\
0.246 \\
0.193 \\
0.268 \\
0.217 \\
0.350\end{array}$ & $\begin{array}{r}m o . \\
3 \\
12 \\
2 \\
3 \\
17 \\
2 \\
3 \\
3 \\
2 \\
2 \\
6 \\
2 \\
11 \\
5\end{array}$ & $\begin{array}{r}w k . \\
3 \\
2 \\
3 \\
0 \\
3 \\
3 \\
2 \\
1 \\
3 \\
0 \\
3 \\
1 \\
1 \\
2\end{array}$ \\
\hline \multicolumn{2}{|c|}{ \% Difference } & -53.9 & -18.1 & -20.7 & -44.8 & & -38 & -91 & \\
\hline
\end{tabular}

could be traced to previous intestinal disturbances; three of the children suffered from pyloric stenosis, one child from a brain tumor and one child from a Wilms tumor.

By eliminating the older children and the children in whom malnutrition was caused by other pathology than preceding diarrheal disease, a group of 13 children can be extracted whose age and clinical pathology are comparable and who lend themselves to a more detailed analysis.

\section{RESULTS}

\section{Physical status}

Table II shows the changes in body weight, height and surface in these 13 selected children who had undergone severe malnutrition.
The physical measurements show that during chronic malnutrition these infants had lost, or failed to achieve on the average, 53.9 per cent of their weight, 44.8 per cent of their calculated weight, 18.1 per cent of the height, 20.7 per cent of the chest circumference and 38 per cent of the body surface if compared with the standard values of the same age. The Grid method (10) for the evaluation of speed and direction of development of each individual child could not be employed to its full advantage because the time of. observation was not long enough. If it is permissible, however, to determine the developmental level line

TABLE III

Hematocrit and hemoglobin of 13 marasmic infants

\begin{tabular}{|c|c|c|c|c|c|c|c|c|}
\hline No. & Hematocrit & Hemoglobin & $\begin{array}{c}\text { Total } \\
\text { circul. } \\
\text { red cell } \\
\text { mass }\end{array}$ & $\begin{array}{c}\text { Total } \\
\text { circul. } \\
\text { hemogl. }\end{array}$ & $\begin{array}{r}\text { Total } \\
\text { circul. } \\
\text { hemogl. }\end{array}$ & $\begin{array}{c}\text { Total } \\
\text { circul. } \\
\text { hemogl. }\end{array}$ & $\begin{array}{c}\text { Total } \\
\text { ciroul. } \\
\text { hemogl. }\end{array}$ & $\begin{array}{c}\text { Total } \\
\text { circul. } \\
\text { hemogl. }\end{array}$ \\
\hline $\begin{array}{c}0522 \\
\text { Sc. } \\
0627 \\
1082 \\
336 \\
1019 \\
0604 \\
0700 \\
\text { Lang. } \\
1110 \\
\text { Mir. } \\
0850 \\
343 \\
\text { Average } \\
\text { Normal }\end{array}$ & $\begin{array}{l}\% \\
24.0 \\
33.4 \\
31.0 \\
27.3 \\
20.5 \\
34.4 \\
32.2 \\
31.5 \\
28.5 \\
27.5 \\
34.0 \\
34.0 \\
24.0 \\
29.4 \\
35.5\end{array}$ & $\begin{array}{r}\text { gm. \% } \\
8.1 \\
11.4 \\
10.5 \\
9.3 \\
6.9 \\
11.7 \\
10.7 \\
10.7 \\
9.7 \\
9.4 \\
11.6 \\
11.6 \\
7.8 \\
9.9 \\
11.8\end{array}$ & $\begin{array}{r}c c . \\
73.7 \\
311.3 \\
76.3 \\
55.1 \\
99.6 \\
90.5 \\
89.2 \\
75.6 \\
131.1 \\
86.1 \\
176.8 \\
\\
120.0 \\
116.1 \\
163.3\end{array}$ & $\begin{array}{r}\boldsymbol{g m} . \\
24.9 \\
107.2 \\
25.8 \\
18.8 \\
33.5 \\
30.8 \\
29.6 \\
25.7 \\
44.6 \\
29.4 \\
60.3 \\
39.0 \\
39.1 \\
54.3\end{array}$ & $\begin{array}{r}\text { per } \mathbf{k g} . \\
\text { act. wt. } \\
8.9 \\
24.4 \\
9.6 \\
7.8 \\
6.4 \\
8.8 \\
10.0 \\
10.0 \\
15.4 \\
10.0 \\
15.1 \\
\\
8.1 \\
11.2 \\
7.4\end{array}$ & $\begin{array}{r}\text { per } \mathbf{k g} . \\
\text { calc. wi. } \\
6.9 \\
16.7 \\
7.2 \\
6.7 \\
5.3 \\
8.3 \\
8.0 \\
10.0 \\
11.0 \\
8.4 \\
11.8 \\
\\
6.8 \\
8.9 \\
7.2\end{array}$ & $\begin{array}{c}\text { per cm. } \\
\text { ht. } \\
0.46 \\
1.62 \\
0.51 \\
0.38 \\
0.52 \\
0.56 \\
0.58 \\
0.55 \\
0.86 \\
0.60 \\
1.00 \\
\\
0.64 \\
0.69 \\
0.81\end{array}$ & $\begin{array}{r}\text { per sq.m. } \\
\text { surface } \\
124.5 \\
375.6 \\
135.7 \\
110.5 \\
111.6 \\
138.1 \\
151.7 \\
149.4 \\
227.5 \\
158.0 \\
245.1 \\
\\
145.6 \\
172.7 \\
155.1\end{array}$ \\
\hline$\%$ Difference & -17.2 & -16.1 & -28.8 & -27.9 & +51.3 & +23.6 & -14.7 & +11.3 \\
\hline
\end{tabular}


for each child from the age, weight and height figures and to compare their average with the performance standard on the speed of development for babies of "average" advancement of the same age, then the projection from the auxodrome on the age scale results in a retardation of development of five and a half months.

\section{Hematocrit and hemoglobin}

The results of hematocrit and hemoglobin determination (Table III) show that there is a decrease of 17.2 per cent in the hematocrit and of 16.1 per cent in the hemoglobin concentration as compared with normal values of hematocrit (11) and hemoglobin (12) for this age. This decrease in hemoglobin production became more marked when the value of the total circulating hemoglobin was derived from hemoglobin concentration and blood volume. Also the total circulating red cell mass was decreased. The ratio of total circulating hemoglobin to units of weight, height and body surface shows that in infants hemoglobin does not seem to be destroyed to a greater degree than other body tissue.

\section{Plasma proteins}

Plasma protein concentration (Table IV) shows a decrease of 6.4 per cent if compared with normal values for this age (13). If the total circulating

TABLE IV

Plasma protein in 13 marasmic infants

\begin{tabular}{c|r|r|r|r|r|r}
\hline \hline No. & $\begin{array}{c}\text { Plasma } \\
\text { protein }\end{array}$ & $\begin{array}{r}\text { Total } \\
\text { circul. } \\
\text { plasma } \\
\text { protein }\end{array}$ & $\begin{array}{r}\text { Total } \\
\text { circul. } \\
\text { plasma } \\
\text { protein }\end{array}$ & $\begin{array}{r}\text { Total } \\
\text { circul. } \\
\text { plasma } \\
\text { protein }\end{array}$ & $\begin{array}{r}\text { Total } \\
\text { circul. } \\
\text { plasma } \\
\text { protein }\end{array}$ & $\begin{array}{r}\text { Total } \\
\text { circul. } \\
\text { plasma } \\
\text { protein }\end{array}$ \\
\hline & gm. \% & gm. & $\begin{array}{c}\text { per } \text { kg. } \\
\text { act. wt. }\end{array}$ & $\begin{array}{c}\text { per } \text { kg. } \\
\text { calc. wi. }\end{array}$ & $\begin{array}{r}\text { per cm. } \\
\text { ht. }\end{array}$ & $\begin{array}{c}\text { per sq.m. } \\
\text { surface }\end{array}$ \\
0522 & 4.47 & 10.5 & 3.7 & 2.9 & 0.19 & 52.5 \\
Sc. & 6.18 & 39.0 & 8.8 & 6.1 & 0.59 & 13.9 \\
0627 & 5.12 & 8.7 & 3.2 & 2.4 & 0.17 & 45.8 \\
1082 & 6.83 & 10.2 & 4.2 & 3.6 & 0.21 & 58.6 \\
336 & 7.18 & 27.8 & 5.3 & 4.3 & 0.43 & 92.3 \\
-1091 & 6.83 & 11.9 & 3.4 & 3.2 & 0.22 & 53.4 \\
0604 & 7.18 & 13.6 & 4.7 & 3.6 & 0.26 & 69.7 \\
0700 & 5.83 & 10.0 & 4.0 & 4.0 & 0.22 & 58.1 \\
Lang. & 5.83 & 19.2 & 6.5 & 4.8 & 0.37 & 97.9 \\
1110 & 5.81 & 13.1 & 4.7 & 3.7 & 0.26 & 70.5 \\
Mir. & 4.80 & 17.3 & 4.2 & 3.3 & 0.30 & 70.3 \\
0850 & 4.80 & & & & & \\
343 & 4.43 & 16.9 & 3.5 & 2.9 & 0.28 & 63.1 \\
Average & 5.8 & 16.5 & 4.7 & 3.7 & 0.29 & 62.2 \\
Normal & 6.2 & 17.4 & 2.3 & 2.3 & 0.26 & 49.7 \\
\hline \% Differ- & & & & & & \\
ence & -6.4 & -5.1 & +104.3 & +60.8 & +11.6 & +25.1 \\
\hline
\end{tabular}

TABLE V

Plasma albumin and globulin in eight marasmic infants

\begin{tabular}{c|c|c|c}
\hline \hline No. & Albumin & Globulin & A/G \\
\cline { 2 - 3 } & gm. \% & gm. \% & \\
0522 & 3.01 & 2.04 & 1.47 \\
1082 & 4.52 & 2.10 & 2.15 \\
336 & 4.43 & 2.53 & 1.75 \\
0604 & 3.49 & 2.48 & 1.41 \\
Lang. & 3.62 & 2.14 & 1.69 \\
1110 & 3.99 & 2.31 & 1.71 \\
Mir. & 3.00 & 2.12 & 1.40 \\
343 & 3.09 & 1.67 & 1.80 \\
Average & 3.64 & 2.17 & 1.64 \\
Normal & 4.6 & 1.30 & 3.50 \\
\hline \% Difference & -20.8 & +66.9 & -53.1 \\
\hline
\end{tabular}

plasma protein is calculated by multiplication with the plasma volume then the decrease amounts to 5.1 per cent. This is due to an increased plasma volume as can be shown also by the relation of total circulating plasma protein to the unit of body weight, height and surface.

The determination of the albumin and globulin fractions (Table V) shows that the decrease in the plasma protein concentration is due entirely to the decrease in albumin concentration. The globulin fraction shows an increase which is equal to the reduction in the albumin fraction. Thus the albumin-globulin ratio is reduced to half of its normal value for this age group (13).

The non-protein nitrogen was in normal ranges in all except two cases of extreme inanition in which it rose to levels of 41 and $49 \mathrm{mg}$. per cent.

\section{Plasma and blood volume}

The determination of plasma volumes (Table VI) shows that the absolute value did not change significantly during severe malnutrition as compared with normal values of the same age group (14). If the absolute value is related to the actual weight and to body surface, however, the plasma volume exceeds by far the normal values.

The absolute values for the blood volume (Table VII) are 14.1 per cent lower in severe malnutrition in infancy if compared with normal values of the same age group (14). If the blood volume is related to the unit of body weight or body surface an increase of 77.7 per cent and 32.8 per cent results. No significant change occurs in the relation of blood volume to unit of body height. 
TABLE VI

Plasma volume in 13 marasmic infants

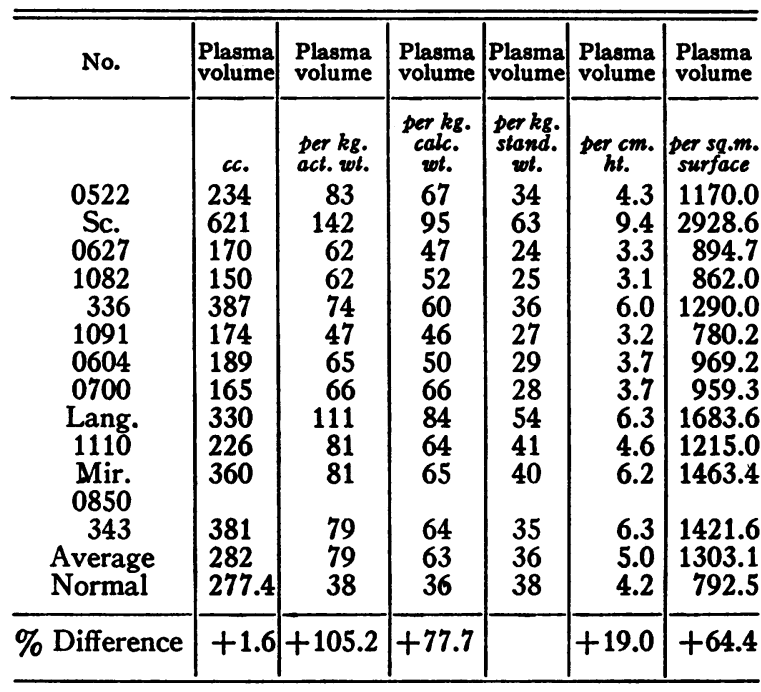

\section{Extracellular fluid}

Table VIII shows the results of the determinations of extracellular fluid space. There is a decrease of 57.5 per cent in the absolute values of the total extracellular fluid space if compared with the available fluid space of newborn infants (15). If related to the unit of weight no significant change occurs if the extracellular fluid space is compared with the same ratio of newborn infants. The extracellular fluid space in malnourished infants decreases to 49 per cent and to

TABLE VII

Blood volume in 13 marasmic infants

\begin{tabular}{c|c|c|c|c|c|c}
\hline \hline No. & $\begin{array}{c}\text { Blood } \\
\text { volume }\end{array}$ & $\begin{array}{c}\text { Blood } \\
\text { volume }\end{array}$ & $\begin{array}{c}\text { Blood } \\
\text { volume }\end{array}$ & $\begin{array}{c}\text { Blood } \\
\text { volume }\end{array}$ & $\begin{array}{c}\text { Blood } \\
\text { volume }\end{array}$ & $\begin{array}{c}\text { Blood } \\
\text { volume }\end{array}$ \\
\hline & & $\begin{array}{c}\text { per kg. } \\
\text { act. }\end{array}$ & $\begin{array}{c}\text { per kg. } \\
\text { calc. } \\
\text { wt. }\end{array}$ & $\begin{array}{c}\text { per } k g . \\
\text { stand. } \\
\text { wt. }\end{array}$ & $\begin{array}{c}\text { per } \\
\text { cm. } \\
\text { ht. }\end{array}$ & $\begin{array}{c}\text { per } \\
\text { sq.m. } \\
\text { surface }\end{array}$ \\
0522 & 307 & 109 & 86 & 45 & 5.7 & 1535.0 \\
Sc. & 932 & 214 & 145 & 95 & 14.1 & 3328.5 \\
0627 & 246 & 91 & 60 & 43 & 4.9 & 1294.7 \\
1082 & 202 & 84 & 70 & 33 & 4.2 & 1160.9 \\
336 & 486 & 93 & 76 & 45 & 7.5 & 1620.0 \\
1091 & 263 & 75 & 69 & 41 & 4.8 & 1179.3 \\
0604 & 277 & 95 & 73 & 42 & 5.4 & 1420.5 \\
0700 & 240 & 96 & 96 & 41 & 5.2 & 1395.3 \\
Lang. & 460 & 155 & 117 & 75 & 8.9 & 2350.0 \\
1110 & 313 & 113 & 89 & 56 & 6.4 & 1682.7 \\
Mir. & 520 & 117 & 94 & 57 & 9.0 & 2113.9 \\
0850 & 500 & 100 & 87 & 46 & 8.3 & 1865.7 \\
343 & 500 & 112 & 88 & 51 & 7.0 & 1745.5 \\
Average & 395 & 63 & 61 & 63 & 6.9 & 1314.2 \\
Normal & 460 & 63 & & \\
\hline \% Difference & -14.1 & +77.7 & +44.2 & -19.0 & +1.4 & +32.8 \\
\hline
\end{tabular}

TABLE VIII

Extracellular fluid in 13 marasmic infants

\begin{tabular}{c|c|c|c|c|c|c}
\hline \hline No. & EFS & EFS & EFS & EFS & EFS & EFS \\
\hline & & $\begin{array}{c}\text { per } k g . \\
\text { act. }\end{array}$ & $\begin{array}{c}\text { per } k g . \\
\text { calc. } \\
\text { wt. }\end{array}$ & $\begin{array}{c}\text { per kg. } \\
\text { stand. } \\
\text { wt. }\end{array}$ & $\begin{array}{c}\text { per } \\
\text { cm. } \\
\text { ht. }\end{array}$ & $\begin{array}{c}\text { per } \\
\text { sq.m. } \\
\text { surface }\end{array}$ \\
0522 & 1090 & 38.9 & 31.5 & 16.0 & 20.3 & 5450.0 \\
Sc. & 1935 & 44.2 & 30.2 & 19.0 & 29.3 & 6910.5 \\
0627 & 1032 & 38.2 & 28.6 & 18.1 & 20.4 & 5431.5 \\
1082 & 699 & 29.1 & 24.6 & 11.6 & 14.4 & 4017.2 \\
336 & 1818 & 35.0 & 29.0 & 17.0 & 28.4 & 6060.0 \\
1091 & 883 & 25.9 & 23.5 & 13.9 & 16.2 & 3959.6 \\
0604 & 909 & 31.3 & 24.2 & 14.2 & 17.8 & 4661.5 \\
0700 & 882 & 35.2 & 35.2 & 15.0 & 18.9 & 5127.9 \\
Lang. & 993 & 33.6 & 25.4 & 16.2 & 19.2 & 5066.3 \\
1110 & 1250 & 45.0 & 35.7 & 22.7 & 25.5 & 6720.4 \\
Mir. & 1580 & 39.7 & 32.0 & 19.6 & 27.4 & 6422.8 \\
0850 & 1250 & 43.7 & 32.8 & 22.3 & 24.7 & 6476.6 \\
343 & 1818 & 36.5 & 27.4 & 16.8 & 30.0 & 6783.6 \\
Average & 1241 & 36.6 & 29.2 & 17.1 & 22.5 & 5622.1 \\
Normal & 2920 & 40.0 & 38.4 & 40.0 & 44.2 & 8342.7 \\
\hline \% Difference & 57.5 & -8.5 & -23.9 & -57.2 & -49.0 & -32.6 \\
\hline
\end{tabular}

32.6 per cent if related to the unit of body height and surface.

If the absolute values for total circulating blood proteins and body fluid volumes are related to the various physical measurements, it is of interest to note that of all relations the one to calculated weight follows most closely the one to body surface.

\section{Sodium and chloride}

Sodium determinations in the plasma of six children showed slightly decreased values with an average of $135 \mathrm{~m}$. Eq. per $1000 \mathrm{ml}$. Also the chloride in the plasma of 12 children was slightly reduced with an average value of $92.3 \mathrm{~m}$. Eq. per $1000 \mathrm{ml}$.

\section{CORRELATION .OF FINDINGS}

By establishing correlations between hemoglobin and plasma protein on one side and plasma volume and extracellular space on the other side, it is possible to elucidate the dynamics of these factors during different stages of malnutrition. Data taken from the study of all 29 malnourished children were used for these correlations.

\section{Plasma protein-extracellular fluid}

Figure 1 shows an inverse correlation between the level of plasma protein and the size of the extracellular space. The existence of this correlation, however, does not necessarily reflect on the 


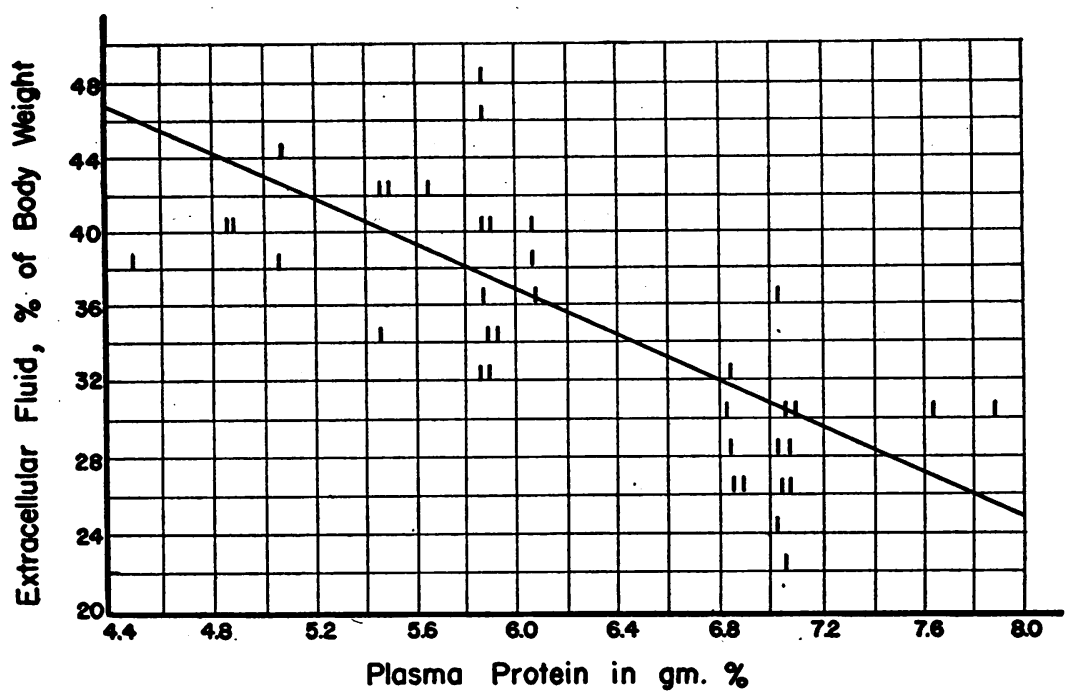

Fig. 1. Correlation between Plasma Protein Concentration and Extracellular Fluid Space

etiology of nutritional edema. In the group of malnourished infants we studied clinical signs of edema were absent even when the extracellular fluid space exceeded 40 per cent of body weight.
Plasma protein-plasma volume

The inverse correlation between the level of plasma protein and the plasma volume in severe malnutrition shown in Figure 2 indicates that these two factors move in opposite directions. There-

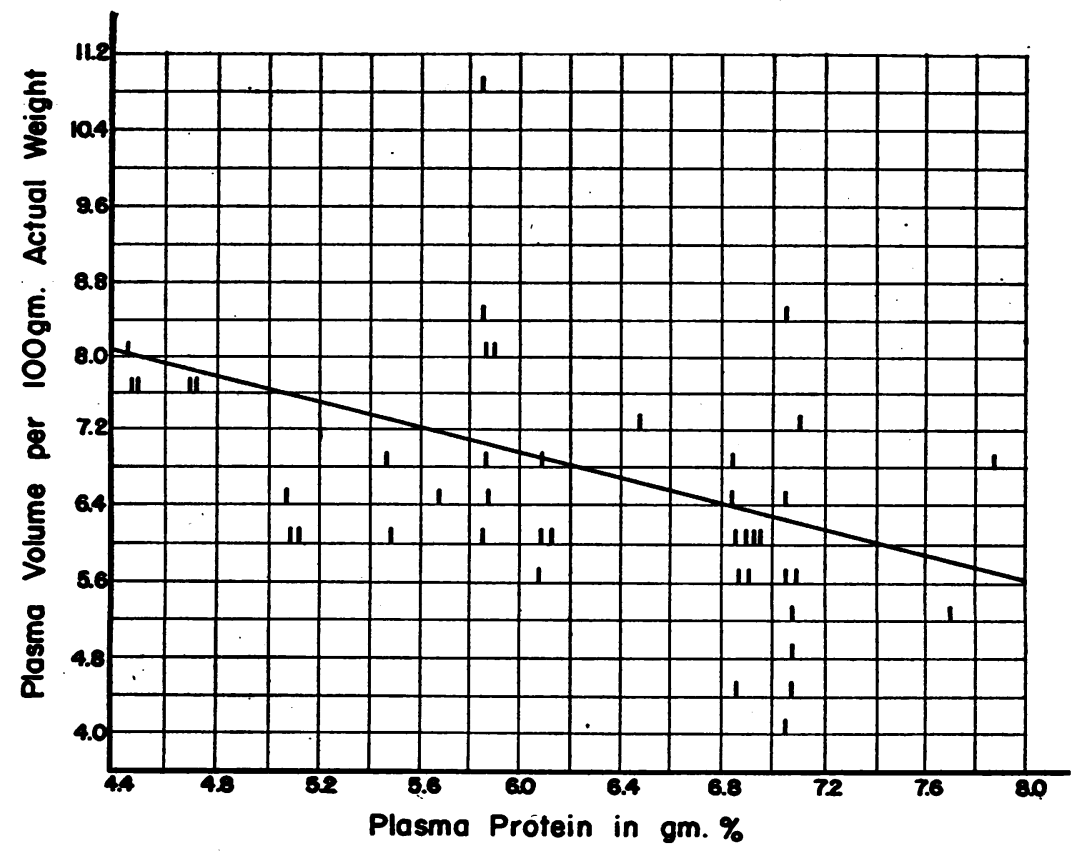

Fig. 2. Correlation between Plasma Protein Concentration and 


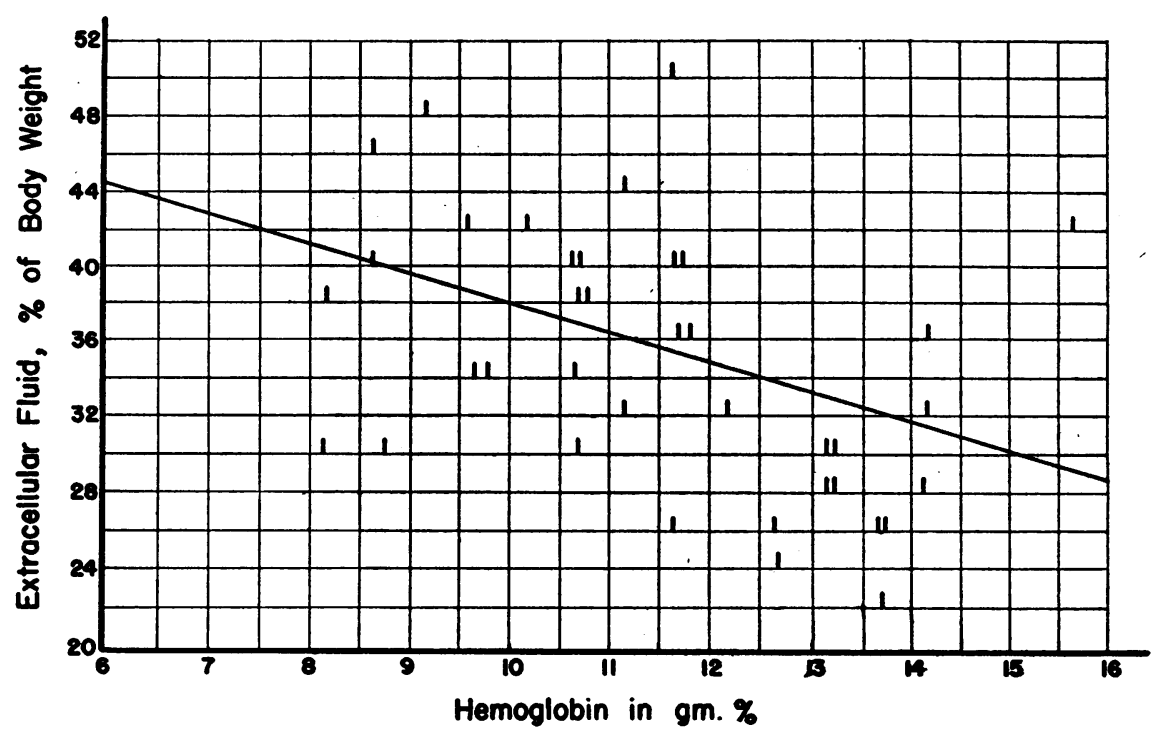

Fig. 3. Correlation between Hemoglobin Concentration and Extracellular Fluid Space

fore a low plasma protein level in malnutrition is related to a dilution factor as well as to reduced production.

\section{Hemoglobin-extracellular fluid}

The same considerations as expressed for the correlation on Figure 1 hold true also for the correlation between the concentration of hemoglobin and the size of the extracellular space on Figure 3. This correlation also indicates more the increasing divergence of hemoglobin and extracellular space with the progressive severity of malnutrition than actual evidence for the etiology of the expansion of extracellular fluid space.

Plasma protein-disappearance rate of $T-1824$ In calculating the disappearance rate of the dye

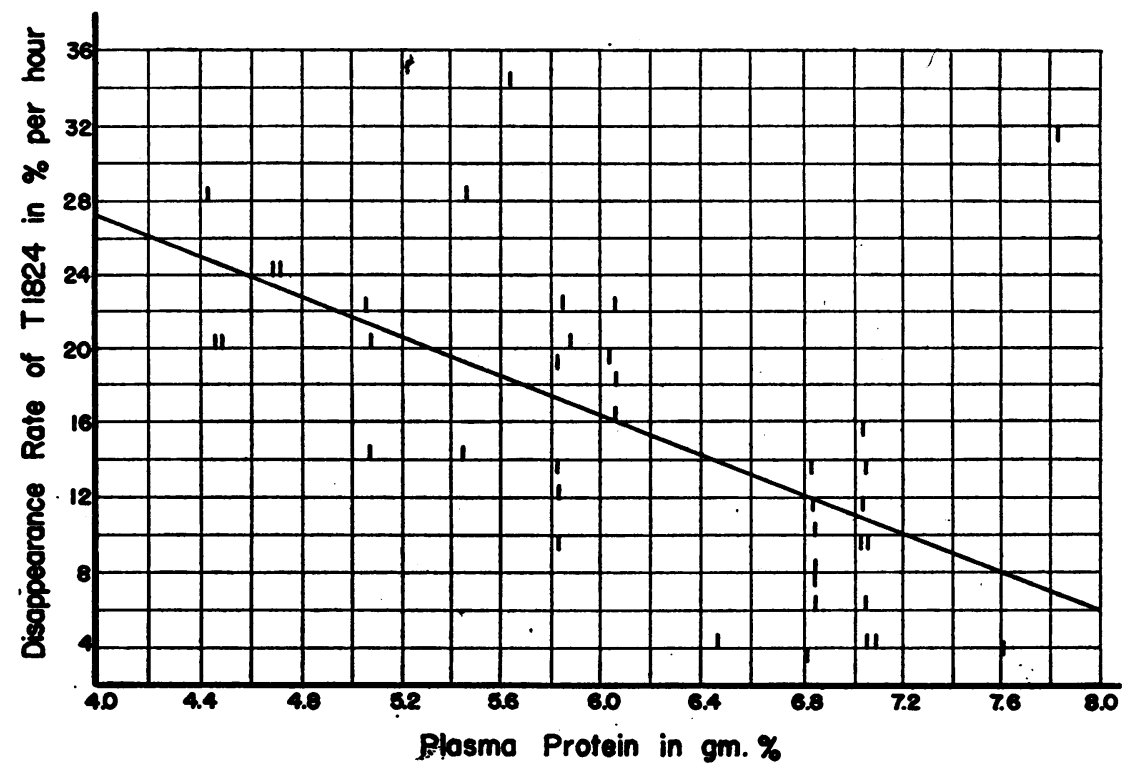

Fig. 4. Correlation between Plasma Protein Concentration and the Disappearance Rate of the Dye T-1824 
$\mathrm{T}-1824$ in the 20,40 and $60 \mathrm{~min}$. samples of plasma after the injection of the dye we have found a wide variation ranging up to 30 per cent in contrast to about 5.2 per cent per hour in normal adults (16). No information on the disappearance rate of the dye in normal infants at different ages is yet available. This change in the disappearance of the dye in severe malnutrition which averages 16.5 per cent, shows a definite inverse correlation to the level of plasma protein, as shown in Figure 4.

The reliability factors (statistically valuable if higher than 2) for the observed correlations are expressed in the following figures:

Plasma protein versus plasma volume....... 2.29

Plasma protein versus extracellular space..... 4.62

Hemoglobin versus extracellular space....... 2.55

Plasma protein versus disappearance rate.... 3.76

\section{DISCUSSION}

During the war and its aftermath new interest has been focused on the physiology and treatment of severe malnutrition and starvation. Although marasmus in infancy is prevalent in many parts of the world and has been known to pediatricians for a long time, little information has been forthcoming using newer methods of investigation.

Without doubt we are dealing with a very complex condition since a severe wastage of body tissue is superimposed upon blood constituents and body fluids still undergoing physiological changes. In addition, marasmus is not a simple deficiency disease because in its later stages an insufficient intake of food is not the main cause for progressive loss of body weight. Almost 30 years ago Marriott (17) observed that in many instances the food given to an infant is sufficient in calories but is either incompletely digested and absorbed or else is not completely utilized by the body after absorption.

\section{Plasma proteins}

Although there is a marked decrease in the concentration of hemoglobin and plasma protein in infantile marasmus the extremely low levels of blood proteins found in malnutrition and starvation in the adult are very rare (18). In contrast to the starving adult (19) where the loss of hemoglobin is relatively much greater than the loss of other body tissue, the infant maintains its normal ratio of total circulating hemoglobin per unit of body weight and body surface. Only the ratio of total circulating hemoglobin to unit of body weight is reduced, a change which is also most marked in the adult.

Just as in the starving adult, the relative decrease in the total circulating plasma protein is less marked than that of the total circulating hemoglobin (19). However, because of the excessively increased plasma volume the ratio of total circulating plasma protein per unit of body weight, height and surface becomes larger than in the normal child of the same age. Whereas in the starving adult plasma protein is not greatly reduced relative to other body tissue (19), in the severely malnourished infant the rapid growth impulse combined with the increased plasma volume results in an increased ratio of plasma protein to body measurements.

The reduction in total circulating plasma protein is entirely due to a marked decrease in the albumin fraction. This observation has been made in all studies on malnutrition. Because of the slight increase in the globulin fraction, the total circulating globulin per unit of body measurement is above normal.

The normal values for blood non-protein nitrogen confirm previous observations in infants, as well as renal function tests on cases of starvation at the German concentration camp Belsen (20). Except in cases of gross edema, renal function has been found to be normal.

\section{Blood volume}

Blood volume studies in infants are not made routinely because of the technical difficulties involved: There exists therefore a lack of extensive physiological studies on blood volume in all age groups using methods which are comparable. Table IX shows a tabulation of blood and plasma volume values for normal infants of the same age as the children investigated in the present study.

This survey of the literature shows that the Evans Blue and carbon-monoxide methods give comparable results, since in normal infants of about six months of age the values for blood and plasma volume are in better agreement than the ones obtained by the vital red method. Similar 
TABLE IX

Blood and plasma volume determinations of infants of six months of age by various authors

\begin{tabular}{|c|c|c|c|c|}
\hline Author & Method & $\begin{array}{c}\text { No. } \\
\text { of } \\
\text { cases }\end{array} \mid$ & $\begin{array}{c}\text { Blood } \\
\text { vol- } \\
\text { ume }\end{array}$ & $\begin{array}{l}\text { Plas- } \\
\text { ma } \\
\text { vol- } \\
\text { ume }\end{array}$ \\
\hline $\begin{array}{l}\text { Lucas \& Dearing (21) } \\
\text { Bakwin \& Rivkin (22) } \\
\text { Darrow, Soule \& Buckman (23) } \\
\text { McIntosh (24) } \\
\text { Brines, Gibson \& Kunkel (14) }\end{array}$ & $\begin{array}{l}\text { Vital red } \\
\text { Vital red } \\
\text { Vital red } \\
\text { CO } \\
\text { T } 1824\end{array}$ & $\begin{array}{r}5 \\
18 \\
5 \\
6 \\
3\end{array}$ & $\begin{array}{c}\% \text { of } \\
w t . \\
11.3 \\
9.5 \\
8.9 \\
6.8 \\
5.8\end{array}$ & $\begin{array}{c}\text { \% of } \\
\text { wi. } \\
7.8 \\
6.1 \\
6.0 \\
4.1 \\
3.6\end{array}$ \\
\hline
\end{tabular}

results with the Evans Blue and carbon-monoxide methods have also been obtained in the same normal subjects $(25,26)$.

The interest in blood volume studies in malnourished infants is of long standing. Marriott and Perkins (27), using the vital red method, found a slightly reduced blood volume in malnourished children. Higher values, however, were obtained in infants who might have been considered as convalescing from marasmus. Bakwin and Rivkin (22) studied 30 infants of the age group comparable to our group and found a blood volume of 10 per cent and a plasma volume of 6.8 per cent which is slightly higher than the values for their normal children of the same age. Recently, controlled studies on human volunteers have confirmed these early observations on infants. Henschel, Taylor, Keys and Sturgeon (28) found after 24 weeks of semi-starvation a blood volume increase to 120 per cent of cc. per $\mathrm{kg}$. of body weight-whereas the plasma volume showed an increase to 142.2 per cent. The same facts are born out by observations made on cases of severe and prolonged starvation at Belsen by Mollison (20). Here in subjects who had lost as much as 50 per cent of their body weight, in six male patients the average blood volume was 10.1 per cent and the plasma volume 6.8 per cent of the actual weight. In ten female subjects the blood volume was reduced to 7.9 per cent, but the plasma volume was increased to 6.8 per.cent of actual body weight. Extensive studies have also been made on malnutrition in Indian prisoners of war in the Far East by Walters, Rossiter and Lehmann (19) of the Marasmus Research Team, India Command. Also here the relative decrease in plasma volume was not as great as that of body weight, and during recovery the plasma volume per $\mathrm{kg}$. of body weight rose to figures far in excess of normal. The total blood volume was slightly lower when the patients were admitted and during recovery it was never greatly in excess of normal.

Experimental studies by Utheim (18) on completely starved rabbits which were also deprived of water have shown that the blood volumes fell below the normal values when referred to body surface, as a result of water loss from the body. Correlated to the actual body weight, however, the blood volume remained fairly constant whereas the plasma volume increased slightly. By giving only enough food and water to prevent further loss of weight the plasma volume reached values above the normal for body weight as well as body surface. The same observations were made in hibernating woodchucks by Rasmussen and Rasmussen (29). The blood volume was lowest when the animals contained a maximum of fat. After dormancy and before food was available the percentage of blood volume was high. The most emaciated animals showed the highest percentage of blood volume in proportion of body weight.

Thus, all observations on blood and plasma volume in malnutrition of children, prisoners of war, human volunteers and of experimental animals agree that under the damaging influence of malnutrition and starvation the cellular elements of the body account for the severe loss of weight, whereas the plasma volume does not contract to the same extent and therefore shows a relative increase per unit of weight.

\section{Extracellular fluid}

The total extracellular fluid space undergoes physiological changes during infancy since the ratio of extra- to intracellular fluid diminishes from the fetal period to adulthood. Recent estimations of extracellular water with radio-active sodium showed values of 43.5 per cent in newborn children (15) as compared with 25 per cent of body weight of the adult determined also with tagged sodium (30). Values for normal infants of different ages are not yet available.

In malnutrition the hydration of the extracellular fluid can be expected to be normal or slightly reduced if water deprivation is also present (31), severely reduced if diarrhea is associated with it 
(32) and greatly enlarged, manifesting itself in nutritional edema, if ample fluid and salt intake are permitted (33). The large increase in body water in malnourished infants has been observed 60 years ago by Ohlmüller (34) and has been measured with the thiocyanate method by Robinow and Hamilton (35). The well-controlled studies on human volunteers by Keys and his co-workers (33) have shown that after 12 weeks of semistarvation the extracellular space as measured by the thiocyanate method may show an increase of over 40 per cent.

\section{Edema}

The infants studied in the present observations, whose fluid intake was low, did not show signs of edema. If intravenous fluid therapy had to be administered, however, the children developed edema very rapidly, proving that the inclination to edema in malnutrition can be made manifest if the means for edema are supplied.

In this connection an increase in capillary permeability which is suggested by the increase in the disappearance rate of the dye $\mathrm{T}-1824$, assumes greater possible importance. Concerning the application of the blood volume method with Evans Blue this finding stresses the necessity of measurement of the disappearance rate of the dye whenever nutritional disturbances are present, and changes in the plasma albumin level are expected (36).

Recently serious doubt has been cast on the role which hypoproteinemia may play in the production of edema (37 to 39). Our observations in marasmic infants tend to strengthen the belief that hypoproteinemia and edema in malnutrition (40 to 42) are two co-existent but not causative factors in malnutrition. The low rate of blood flow which in some instances has been found from 80 to 90 per cent less than normal (18) and the reduced oxygen saturation and content of the venous blood (43), may prove to have a closer causative relation of nutritional edema than the low plasma protein concentration.

The treatment of the late stages of infantile marasmus is still unsatisfactory. The administration of intravenous fluid therapy in cases where food cannot be taken orally is contraindicated because plasma volume and extracellular fluid spaces tend to be high and more fluid and salt will lead only to the formation of edema. Blood transfusions are of temporary value only except in cases of severe edema $(19,44)$. The observations reported here conform with the statement of Marriott (17)-that transfusions have a temporary value only unless the underlying cause of body destruction is found and remedied.

Liver biopsies in some of our cases failed to show any destructive lesions of the hepatic parenchyma.

\section{Failure of absorption}

Our experience with the oral administration of casein hydrolysates confirms rather the point of view that failure of absorption seems to be the essential lesion in the irreversible stages of starvation (45). In the case of a completely emaciated 13-year-old girl, well-being and gain in weight could be achieved as long as blood transfusions and large amounts of casein hydrolysates and dextrose by mouth were administered. When casein hydrolysates were no longer available we had to change to milk mixtures which were not tolerated and caused irritation, diarrhea and death. The construction of a diet which would not only meet all the increased nutritional requirements in malnourished children but would also attempt to substitute the specific intracellular substances lost, as successfully employed with potassium chloride infusions in infantile diarrhea (46), may eventually lead to absorption and retention of these elements and to an etiological treatment of infantile marasmus.

\section{SUM MARY}

Blood and extracellular fluid studies were carried out in 13 severely malnourished infants with the following results:

1. Compared with normal infants of the same age there occurred a loss of 53.9 per cent of actual weight, 44.8 per cent of calculated weight, 18.1 per cent of height and 38 per cent of body surface. In speed and direction of development, the marasmic infants of an average age of six months showed a retardation of five and a half months as measured by the Wetzel-Grid method.

2. The hematocrit and the hemoglobin concentration showed a decrease. The total circulat- 
ing hemoglobin was reduced. The ratios of total circulating hemoglobin to unit of body weight, height and surface indicate that in malnourished infants hemoglobin is not destroyed to a greater degree than other body tissue.

3. The concentration of plasma protein and the total circulating plasma protein were reduced. The relation of total circulating plasma protein to unit of body weight, height and surface showed a marked increase.

4. The concentration of albumin was reduced, whereas the concentration of globulin showed an increase, resulting in a low albumin-globulin ratio.

5. The non-protein nitrogen was within normal ranges.

6. The absolute values of plasma volume did not change significantly if compared with normal values of the same age group. When this value was related to the actual weight and body surface, the plasma volume was far in excess of normal and its increase was less if related to body length.

7. The absolute values of blood volume were reduced. The ratio of blood volume to unit body weight and surface showed an increase. No significant change occurred in the relation of blood volume to unit of body height.

8. The disappearance rate of the dye $\mathrm{T}-1824$ from the blood stream was increased.

9. The absolute values of extracellular fluid space were reduced. The relation of extracellular fluid space to unit of body weight did not change significantly. The extracellular fluid space decreased if related to unit of body height and surface.

10. The ratios of total circulating blood proteins and body fluid volumes to calculated weight -a value derived from chest circumference and body height only-followed closely the respective ratios to body surface.

11. The concentrations of sodium and chloride in the plasma were slightly reduced.

12. There existed an inverse correlation between plasma protein and extracellular fluid space, between plasma protein and plasma volume, between hemoglobin and extracellular fluid space and between plasma protein concentration and the disappearance rate of the dye $\mathrm{T}-1824$.

\section{BIBLIOGRAPHY}

1. Grandprey, M. B., Range and variability in weight and height in children under six years of age. Child Development, 1933, 4, 26.

2. Massler, M., Calculation of normal weight. Child Development, 1945, 16, 111.

3. Du Bois, E. F., Basal Metabolism in Health and Disease. Lea \& Febiger, Baltimore, 1936.

4. Phillips, R. A., Van Slyke, D. D., Dole, V. P., Emerson, K., Hamilton, P. B., and Archibald, R. M., Copper sulfate method for measuring specific gravities of whole blood and plasma, with line charts for calculating plasma proteins, hemoglobin and hematocrit from plasma and whole blood gravities. New York: U. S. Navy Research Unit, Hospital of the Rockefeller Inst. for Medical Research, 1943, 51 pp.

5. Greenberg, D. M., Colorimetric determination of serum proteins. J. Biol. Chem., 1929, 82, 545.

6. Wong, S. Y., Colorimetric determination of iron and hemoglobin in blood. J. Biol. Chem., 1923, 55, 421.

7. Gregersen, M. I., and Stewart, J. D., Simultaneous determination of plasma volume with T-1824 and "available fluid" volume with sodium thiocyanate. Am. J. Physiol., 1939, 125, 142.

8. Butler, A. M., and Tuthill, E., An application of the uranyl zinc acetate method for determination of sodium in biological material. J. Biol. Chem., 1931, 93, 171.

9. Van Slyke, D. D., The determination of chlorides in blood and tissues. J. Biol. Chem., 1923-24, 58, 523.

10. Wetzel, N. C., Baby Grid; application of Grid technique to growth and development in infants. J. Pediat., 1946, 29, 439.

11. Wintrobe, M. M., Clinical Hematology. Lea and Febiger, Philadelphia, 1946.

12. Kolmer, J. A., and Boerner, F., Approved Laboratory Technic. D. Appleton-Century Co., New YorkLondon, 1941.

13. Trevorrow, V., Kaser, M., Patterson, J. P., and Hill, R. M., Plasma albumin, globulin, and fibrinogen in healthy individuals from birth to adulthood "normal" values. J. Lab. \& Clin. Med., 1942, 27, 471.

14. Brines, J. K., Gibson, J. G., Jr., and Kunkel, P., Blood volume in normal infants and children. $J$. Pediat., 1941, 18, 447.

15. Flexner, L. B., Wilde, W. S., Proctor, N. K., Cowie, D. B., Vosburgh, G. J., and Hellman, L. M., The estimation of extracellular and total body water in the newborn human infant with radioactive sodium and deuterium oxide. J. Pediat., 1947, 30, 413.

16. Noble, R. P., and Gregersen, M. I., Blood volume in clinical shock. I. Mixing time and disappearance rate of T-1824 in normal subjects and in patients in shock; determination of plasma volume in man from 10-minute sample. J. Clin. Invest., 1946, 25, 158.

17. Marriott, W. M., Some phases of pathology of nutrition in infancy. Am. J. Dis. Child., 1920, 20, 461. 
18. Utheim, K., A study of the blood and its circulation in normal infants and in infants suffering from chronic nutritional disturbances. Am. J. Dis. Child., 1920, 20, 366.

19. Walters, J. H., Rossiter, R. J., and Lehmann, H., Malnutrition in Indian prisoners of war in the Far East. The Lancet, 1947, 252, 205.

20. Mollison, P. L., Observations on cases of starvation at Belsen. Brit. M. J., 1946, 1, 4.

21. Dearing, B. F., and Lucas, W. B., Blood volume in infants estimated by the vital dye method. Am. J. Dis. Child., 1921, 21, 96.

22. Bakwin, H., and Rivkin, $H$., The estimation of the volume of blood in normal infants and in infants with severe malnutrition. Am. J. Dis. Child., 1924, 27, 340.

23. Darrow, D. C., Soule, H. C., and Buckman, T. E., Blood volume in normal infants and children. $J$. Clin. Invest., 1928, 5, 243.

24. McIntosh, R., The determination of the circulating blood volume in infants by the carbon monoxide method. J. Clin. Invest., 1929, 7, 203.

25. Hopper, J., Jr., Tabor, H., and Winkler, A. W., Simultaneous measurements of the blood volume in man and dog by means of Evans blue dye T-1824, and by means of carbon monoxide. I. Normal subjects. J. Clin. Invest., 1944, 23, 628.

26. Root, W. S., Roughton, F. J. W., and Gregersen, M. I., Simultaneous determinations of blood volume by $\mathrm{CO}$ and dye (T-1824) under various conditions. Am. J. Physiol., 1946, 146, 739.

27. Marriott, W. McK., Chronic digestive insufficiency. M. Clinics N. America, 1922, 6, 91.

28. Henschel, A., Taylor, H. L., Keys, A., and Sturgeon, A. M., Blood and plasma changes in semi-starvation and subsequent rehabilitation. Federation Proc., 1947, 6, 129.

29. Rasmussen, A. T., and Rasmussen, G. B., The volume of the blood during hibernation and other periods of the year in the woodchuck (Marmota Monax). Am. J. Physiol., 1917, 44, 132.

30. Kaltreider, N. L., Meneely, G. R., Allen, J. R., and Bale, W. F., Determination of volume of extracellular fluid of body with radioactive sodium. J. Exper. Med., 1941, 74, 569.

31. Kerpel-Fronius, E., Uber die Beziehungen zwischen Salz- und Wasserhaushalt bei experimentellen Wasserverlusten. Ztschr. f. Kinderh., 1935, 57, 489.

32. Nadal, J. W., Pedersen, S., and Maddock, W. G., A comparison between dehydration from salt loss and from water deprivation. J. Clin. Invest., 1941, 20, 691.

33. Henschel, A., Mickelsen, O., Taylor, H. L., and Keys, A., Plasma volume and thiocyanate space in famine edema and recovery. Am. J. Physiol., 1947, 150, 170.

34. Ohlmüller, W., Ueber die Abnahme der einzelnen Organe bei an Atrophie gestorbenen Kindern. Ztschr. f. Biol., 1882, 18, 78.

35. Robinow, M., and Hamilton, W. F., Blood volume and extracellular fluid volume of infants and children. Studies with improved dye micromethod for determination of blood volume. Am. J. Dis. Child., 1940, 60, 827.

36. Rawson, R. A., The binding of T-1824 and structurally related diazo dyes by plasma proteins. Am. J. Physiol., 1943, 138, 708.

37. Stare, F. J., Nutritional conditions in Holland. Nutrition Rev., 1945, 3, 225.

38. Davidson, C. S., Wilcke, H. L., and Reiner, P. J. Nutritional survey of starvation in a group of young men. J. Lab. \& Clin. Med., 1946, 31, 721.

39. Keys, A., Taylor, H. L., Mickelsen, O., and Henschel, A., Famine edema and mechanism of its formation. Science, 1946, 103, 669.

40. Weech, A. A., and Ling, S. M., Nutritional edema. Observations on the relation of the serum proteins to the occurrence of edema and to the effect of certain inorganic salts. J. Clin. Invest., 1931, 10, 869.

41. Bruckman, F. S., D’Esopo, L. M., and Peters, J. P., The plasma proteins in relation to blood hydration. IV. Malnutrition and the serum proteins. J. Clin. Invest., 1930, 8, 577.

42. Maver, M. B., Nutritional edema and "war dropsy." J. A. M. A., 1920, 74, 934.

43. Keys, A., Henschel, A., and Taylor, H. L., The size of and function of the human heart at rest in semi-starvation and in subsequent rehabilitation. Am. J. Physiol., 1947, 150, 153.

44. Vaughan, J., Dent, C., and Rivers, R. P., Discussion; physiology and treatment of starvation; value of hydrolysates in treatment of severe starvation. Proc. Roy. Soc. Med., 1945, 38, 395.

45. Magee, H. E., Cuthbertson, D. P., and Stannus, H., Discussion; physiology and treatment of starvation; starvation and protein hydrolysates. Proc. Roy. Soc. Med., 1945, 38, 388.

46. Govan, C. D., Jr., and Darrow, D. C., The use of potassium chloride in treatment of dehydration of diarrhea in infants. J. Pediat., 1946, 28, 541. 